\begin{tabular}{|c|c|c|c|}
\hline Eiszeitalter u. Gegenwart & $\mathbf{4 5}$ & $32-41$ & Hannover 1995 \\
\hline
\end{tabular}

\title{
Weichselian and Holocene river dynamics in relation to climate change in the Halle-Leipziger Tieflandsbucht (Germany)
}

\author{
JOANNE MOL*)
}

Pleistocene, Holocene, sedimentology, stratigraphy, development of river systems, climatic change, Leipzig, Germany

\begin{abstract}
The exact relationship between river development and climate change is still unknown. Therefore, this study aims to contribute to an increase in knowledge about this topic and focuses on Weichselian and Holocene river development in the Halle-Leipziger Tieflandsbucht (Germany). The results are correlated with data from Poland and the Netherlands. Finally, the impact of climatic changes on river development are explained.

Changes in vegetation cover, related to changes in climate, trigger the onset of each new river system, which starts with an erosion phase. Nevertheless, this study shows that climate changes not only cause erosion-deposition cycles, but also changes in sedimentology within a river system.
\end{abstract}

\section{[Weichselzeitliche und holozäne Flußdynamik in Beziehung zu Klimaänderungen in der Halle- Leipziger Tieflandsbucht (Deutschland)]}

Kurzfassung: Die genaue Beziehung zwischen Flußentwicklung und Klimaänderung ist noch immer nicht deutlich. Mit dieser Arbeit ist beabsichtigt, einen Beitrag zu leisten für die Zunahme von Kenntnissen über dieses Thema. Die Arbeit konzentriert sich auf die weichselzeitliche und holozäne Flußentwicklung in der Halle-Leipziger Tieflandsbucht (Deutschland). Die Ergebnisse werden mit Daten von Polen und der Niederlande korreliert. Schließlich wird die Bedeutung von Klimaänderungen auf die Flußentwicklung erläutert.

Änderungen in Vegetationbedeckung, im Zusammenhang mit Klimaänderungen, bewirken den Anfang eines neuen Flußsystems, das anfängt mit einer Erosionsphase. Trotzdem, es zeigt sich, daß Klimaänderungen nicht nur neue Erosions-Sedimentations-Zyklen zur Folge haben, sondern auch Änderungen in der Sedimentologie eines Flußsystems.

\section{Introduction}

This study aims to increase the knowledge about the response of rivers on climate change. River development in general is relatively well documented. However, river development in relation to climate change has caught attention only recently and as a result, a limited amount of data is available. Weich-

*) Address of the author: Frau Joanne MoL, Vrije Universiteit, Institute of Earth Sciences, De Boelelaan 1085, 1081 HV Amsterdam, The Netherlands selian river development, for instance, has been studied thoroughly in the Netherlands and in Poland (PONS 1957, BARTKOWSKI 1957), but only in later phases, attempts have been made to correlate these developments with climate changes (KOZARSKI 1983, VANDENBERGHE et al. 1987, VANDENBERGHE 1993).

The investigation of Weichselian river sediments in Germany will allow correlation of Polish and Dutch findings and will give more insight in the Weichselian river development in relation to climate change on a larger scale. Although Holocene and Weichselian river development in Germany seems also relatively well documented, most of the studies focus on stratigraphy and chemical characteristics, rather than the genesis of the river systems. This makes correlation with Poland and the Netherlands difficult. Therefore, this investigation attempts to gather more data of Weichselian river development in relation to climate change in the Halle-Leipziger Tieflandsbucht (Germany), where large exposures are present. The latter provide excellent opportunities to investigate the Pleistocene deposits (EISSMann 1975). The present research deals with the sedimentary characteristics and periglacial features of the Weichselian and Holocene fluvial deposits of the Weisse Elster river in two open cast mines within this area: Merseburg-Ost and Cospuden (Fig. 1). This study not only aims to describe the genesis of the Weisse Elster river, but also to record age and duration of periods of erosion and deposition, since they reflect a reaction of a river system on changed conditions. Finally, the inferred regional modifications of the river system are explained and correlated with the Polish and Dutch findings.

\section{Previous work}

During the Weichselian, rivers in Poland and the Netherlands showed a similar pattern of development. At the Middle-Late Pleniglacial boundary (27 ka) fluvial activity started with an erosion in both countries (VAN HuISSTEDEN et al. 1986, KRZYSZKOwsKIJ 1990). In the Netherlands, the Late Pleniglacial 


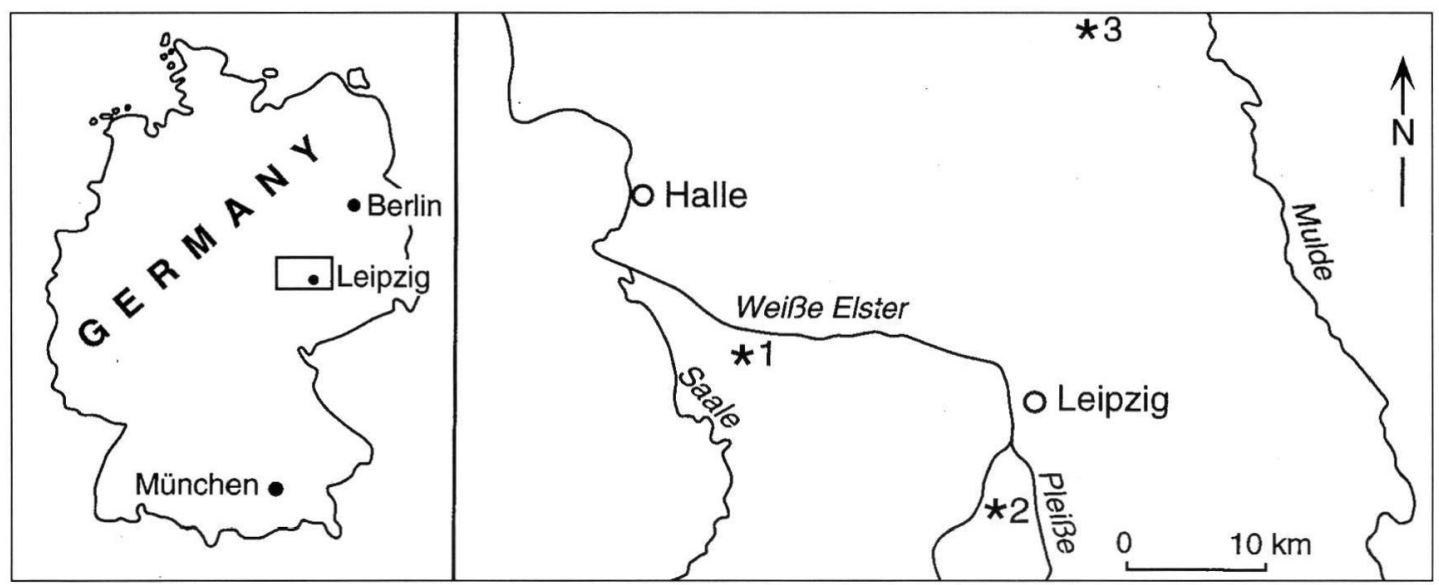

Fig. 1: Location of the studied exposures, $1=$ open cast mine Merseburg-Ost, $2=$ open cast mine Cospuden, $3=$ open cast mine Goitsche

Abb. 1: Lage der Aufschlüsse, 1 = Tagebau Merseburg-Ost, 2 = Tagebau Cospuden, 3 = Tagebau Goitsche.

fluvial activity was restricted to the first part of the Late Pleniglacial. Aeolian processes dominated the last part of the Late Pleniglacial and fluvial activity was minor, caused by a dry climate (VAN HuISSTEDEN et al. 1986, BoHnCKE et al. 1987). KozARSki (1983) found a transition from braided to meandering river systems at the onset of the Late Glacial (13-10 ka). He also reported new erosion and development of a second meandering river system, that took place at the onset of the Holocene in Poland. This corresponded with the fluvial development in the Netherlands (VANDENBERGHE et al. 1987).

In Germany, the Weichselian fluvial deposits were grouped morphologically in low terrace deposits, previously attributed to the Weichselian Early Glacial and Pleniglacial periods. Most authors assumed that fluvial activity ceased during the maximum glaciation (circa $18 \mathrm{ka}$ ), which was characterized by severe dryness (Ruske $\&$ WÜnsChe 1964, SCHALICH 1968; EISSMANN 1975). In 1967, STEINMÜLLER confirmed this with a date of $22 \mathrm{ka} \mathrm{BP}$ for the upper part of the low terrace deposits.

Nevertheless, Hiluer et al. showed in 1991 that the low terrace deposits were not as old as previously believed, but dated from the end of the Middle Pleniglacial. They dated two levels of (reworked) peat at $2-4 \mathrm{~m}$ from the base of the low terrace (site 3 in Fig 1) 26 - $30 \mathrm{ka} \mathrm{BP}$, which indicated a Middle to Late Pleniglacial age for the start of deposition of the low terrace. This confirmed the dates of STEINMÜLLeR (1967). In contrast, WOLF \& SEIFERT (1991) interpreted a peat layer on top of the low terrace as Brørup, based on palynological analyses. Thus, they concluded that the low terrace was pre-Brørup, although they could not prove a post-Eemian age for their low terrace deposits.

The Late Glacial and Holocene river dynamics are documented well. Various authors reported incised channels of meandering river systems of both Late Glacial and Holocene age (Brosche 1984, Wolf \& Seifert 1991, Hiller et al. 1991). After the Early Atlantic, increased agricultural activities resulted in an increased sediment load, and caused deposition of large quantities of overbank loam („Auelehm“) (HiLLER et al. 1991, LITT 1992).

\section{The development of the Weisse Elster River}

Three different river systems are differentiated on the basis of their sedimentary characteristics, periglacial features and erosion base: the lower, middle and upper river systems. Erosion phases characterize the onset of the systems. It will be shown that the lower river system is a braided river system, that is deposited during permafrost conditions and is dominated by gravel. The middle and the upper river systems are both meandering river systems, that are dominated by silt, but the middle river system is disturbed periglacially, while the upper river system is not.

The lower river system

The lower system forms the low terrace, a morphologically distinct feature in this area (EISSMANN 1975 , WOlF \& SeIFerT 1991). The deposits of the low terrace have a maximum thickness of $7 \mathrm{~m}$. Stacked bar sequences, heterogeneous grain size composition and dominance of gravel characterize the lower river system. The stacked bar sequences suggest frequent lateral shifting. Together with the dominance of gravel and the heterogeneous grain size of the deposits, this points to braided river conditions.

Figures 2 and 3 illustrate the lower river system and show its development. The entire section consists of stacked bar sequences. They represent deposits of bars, that migrate either into an active channel or on the nearest bar (RUST \& Koster 1984). The subdivi- 
sion of the bar sediments into an lower and an upper part (Fig 2) is due to a change from relatively deep to shallow water conditions: a low ratio of water depth to mean particle size suppresses development of cross strata on bars (Rust 1978). Therefore, figure 2 clearly reflects a decrease in water depth upward and shows two phases of different river activity within one river system. Nonetheless, this is only the case in Merseburg-Ost. In Cospuden, massive imbricated gravel, which points to shallow water conditions, dominates the entire section (Fig. 3). This indicates that during the first phase river activity in deeper channels was confined to a certain active tract and that only during flash floods a larger area served for storage (REINFELDS \& NANSON 1993).

During the second phase of the river system, both the Merseburg-Ost and Cospuden exposures point to shallow water conditions. This is caused by either movement of the active tract or a decrease in discharge. The river system probably had a decreased discharge during its last phase, since in a nearby exposure (open cast mine Goitsche, Fig 1) the lithology changes upward from gravel to sand (Hiller et al. 1991). This also indicates a diminished flow

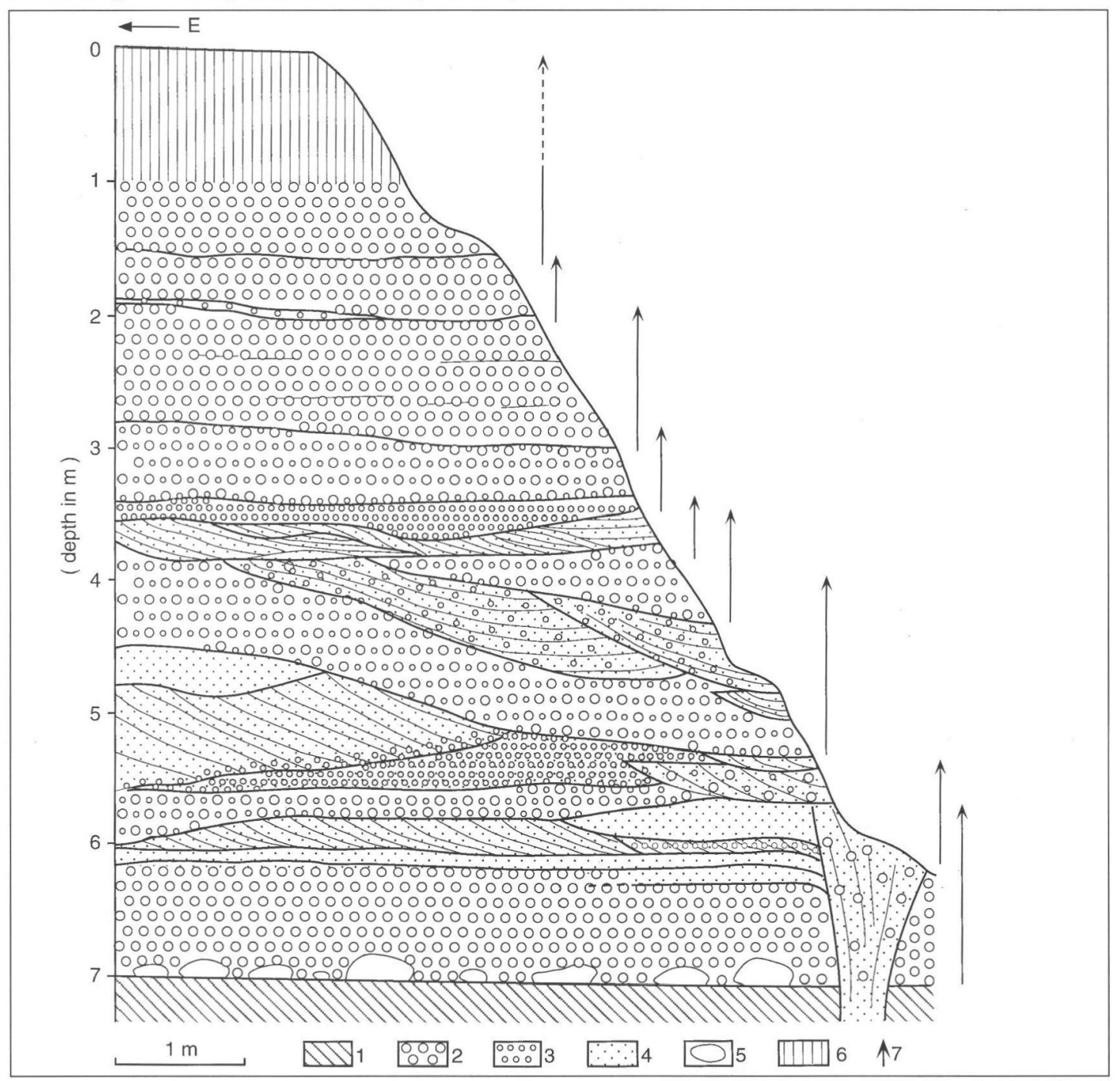

Fig. 2: Deposits of the lower river system in Merseburg-Ost, that represent mainly stacked bar sequences (indicated with arrows). The section is subdivided into two parts with different sedimentary characteristics: planar cross stratificated gravel and massive imbricated gravel dominate the lower part, whereas massive imbricated gravel alone characterizes the upper part of the section, $1=$ brown coal (substratum), $2=$ coarse gravel $(0.5-5 \mathrm{~cm}), 3=$ fine gravel $(<0.5 \mathrm{~cm}), 4=\operatorname{sand}$, $5=$ cobbles $(5-25 \mathrm{~cm}), 6=$ soil, $7=$ bar sequence

Abb. 2: Sedimente des unteren Flußsystems in Merseburg-Ost, die die übereinanderliegenden Banksequenzen repräsentieren (angegeben mit Pfeil). Das Profil ist in zwei Teile gegliedert worden: im unteren Teil gibt es vorherrschend ebene schräggeschichtete Kiese und 'massive imbricated' Kiese, weil im oberen Teil nur 'massive imbricated' Kies vorherrscht, $1=$ Braunkohle, $2=$ Kies $>0,5 \mathrm{~cm}$, $3=$ Kies $<0,5 \mathrm{~cm}, 4=$ Sand, $5=$ Steine $(5-25 \mathrm{~cm}), 6=$ Boden, $7=$ Banksequenz. 


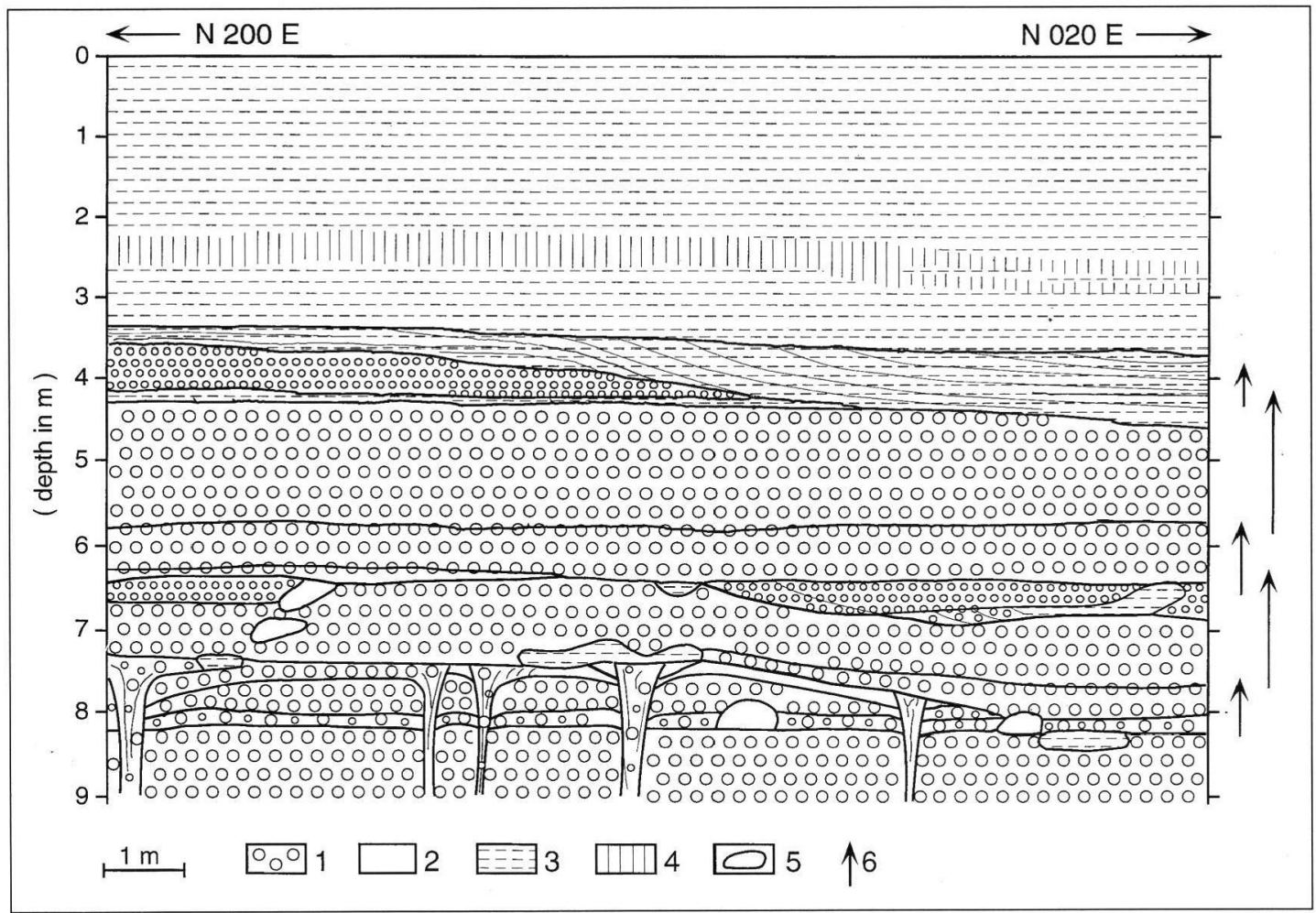

Fig. 3: Deposits of the lower river system in Cospuden, that represent mainly stacked bar sequences (indicated with arrows) of massive imbricated gravel, $1=$ coarse gravel $(0.5-5 \mathrm{~cm}), 2=$ fine gravel $(<0.5 \mathrm{~cm}), 3=$ silt, $4=$ soil, $5=$ cobbles $(5-25 \mathrm{~cm}), 6=$ bar sequence.

Abb. 3: Sedimente des unteren Flußssystems in Cospuden, die die übereinanderliegende Banksequenzen von 'massive imbricated' Kies repräsentieren (angegeben mit Pfeil). $1=$ Kies $>0,5 \mathrm{~cm}, 2=$ Kies $<0,5 \mathrm{~cm}, 3=$ Schluff, $4=$ Boden, $5=$ Steine $(5-25 \mathrm{~cm}), 6=$ Banksequenz.

Periglacial phenomena are present as numerous ice wedge casts, which indicate continuous permafrost (Fig 2 and 3). The ice wedges are present in gravel, which points to an extremely low mean annual ground temperature of $-5.5^{\circ} \mathrm{C}$ (ROMANOvskij 1985). VANDENBERGHE (1992) translated this ground temperature to $-8^{\circ} \mathrm{C}$ mean annual air temperature. In both Cospuden and Merseburg-Ost, the ice wedge casts are present at two levels: a lower level on top of the lag deposit, and an upper level at $0.5-1.5 \mathrm{~m}$ above the base of the lower river deposits. Solitary ice-wedge casts at other levels are not present.

Both levels with ice wedge casts represent a hiatus in the sedimentary record, since they need at least several tens to hundreds of years to develop. Deposition on top of both levels must have occurred synchronously: during erosion in the active tract, ice wedges developed on inactive parts (Williams \& Rust 1969, VANDENBerghe \& Van Huissteden 1988).

\section{The middle river system}

The middle river system is characterized by its clear separation of channel fill and overbank deposits. Gravel is present in minor quantities in lag deposits and also in overbank deposits as a result of major floods. In general, the middle river system is low energetic. The middle river system has a maximum thickness of $2 \mathrm{~m}$ and has an erosion base that is $3-4 \mathrm{~m}$ higher than the erosion base of the lower river system.

Figures 4 and 5 illustrate the middle river system. The many channel scars suggest frequent abandonment of the active channels, whereas the overbank deposits point to frequent floods. The flow capacity during those floods must have been extremely large, to deposit the gravel splays. Epsilon cross bedding is not present, although the channel in figure 4 shows some lateral accretion at its base. This could be due to a relatively low sinuosity. Nevertheless, all features point to a meandering river system.

Periglacial phenomena are present only as periglacial involutions. All channel fills of the middle river system (Fig 4 and 5) are cryoturbated. According to VANDENBERGHE (1988) intense seasonal frost is sufficient for formation of these structures. 


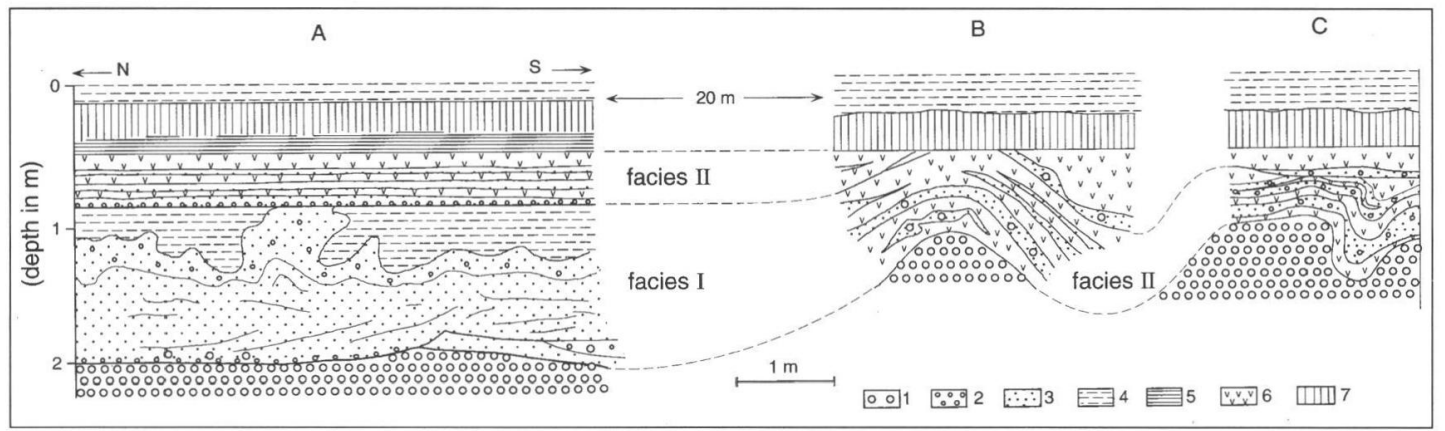

Fig. 4: Deposits of the middle river system in Merseburg-Ost. The braided river deposits of the lower river system are present at the base and a soil marks the boundary with the upper river system. A periglacially disturbed channel fill (facies I) with on top overbank deposits (facies II) in section A are the equivalent of two phases of overbank deposits in sections $\mathrm{B}$ and $\mathrm{C}$ (subdivision based on different cryoturbation phases). The age of the top of the overbank deposits in section $\mathrm{B}$ is palynologically established as end of Younger Dryas (Litt 1992), $1=$ coarse gravel $(>0.5 \mathrm{~cm}), 2=$ fine gravel $(<0.5 \mathrm{~cm})$, $3=$ sand, 4 = silt, 5 = clay, $6=$ peat, $7=$ soil.

Abb. 4: Sedimente des mittleren Flußsystems in Merseburg-Ost. Im Liegenden sind die 'braided river' Sedimente des unteren Flußsystems und im Hangenden ist ein Boden die Grenze zum oberen Flußsystem. Eine periglazial deformierte Rinnenfüllung und Überschwemmungssedimente im Hangenden in Profil A korrelieren mit zwei Phasen von Überschwemmungssedimenten in Profilen B und $\mathrm{C}$ (Gliederung aufgrund verschiedener Kryoturbations-Phasen), $1=$ Kies $>0,5 \mathrm{~cm}, 2=$ Kies $<0,5 \mathrm{~cm}, 3=$ Sand, $4=$ Schluff, $5=$ Ton, $6=$ Torf, $7=$ Boden .

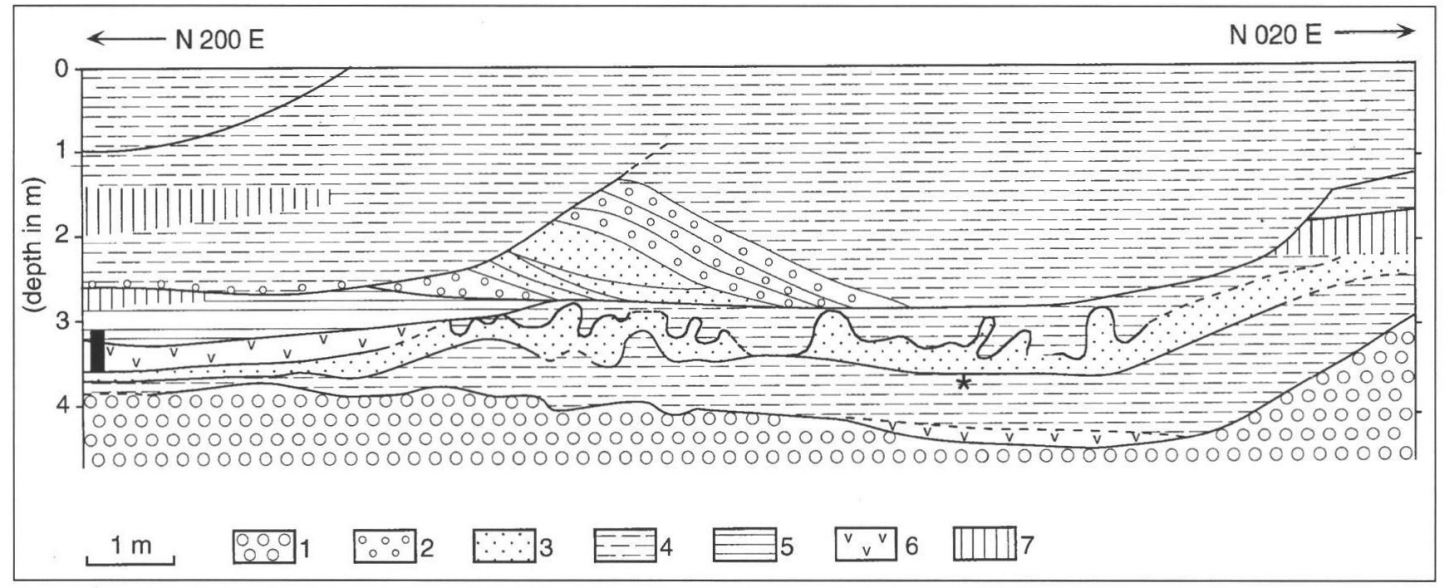

Fig. 5: Deposits of the middle and younger river system (separated by lowest soil) in Cospuden. Substratum consists of gravel of the lower terrace. The middle river system is characterized by three channel fills. Black square indicates location of pollen profile, asterisk indicates location of ${ }^{14} \mathrm{C}$ sample $\mathrm{GrN} 17156(10,260 \pm 110 \mathrm{BP}), 1=\mathrm{coarse}$ gravel $(>0.5 \mathrm{~cm})$, 2 = fine gravel $(<0.5 \mathrm{~cm}), 3=$ sand, $4=$ silt, $5=$ clay, $6=$ peat, $7=$ soil.

Abb. 5: Sedimente der mittleren und oberen Flußsysteme in Merseburg-Ost (Grenze ist der Boden). Das Liegende besteht aus Kiesen des unteren Flußsystems. Das mittlere Flußsystem wird von drei Rinnenfüllungen repräsentiert. Ein schwarzes Quadrat deutet die Lage eines Pollenprofils an und ein Sternchen die Lage einer ${ }^{14} \mathrm{C}$ Probe. $1=$ Kies $>0,5 \mathrm{~cm}, 2=$ Kies $<0,5 \mathrm{~cm}, 3=$ Sand, $4=$ Schluff, $5=$ Ton, $6=$ Torf, 7 = Boden .

\section{The upper river system}

Silt dominates the upper river system. This river system formed the so-called „Aue“ (flood plain) (HiLLer et al. 1991). Its maximum thickness is $3 \mathrm{~m}$ in Merseburg-Ost and it erodes the deposits of the lower river system for several metres. The erosion base of the upper river system is $5-6 \mathrm{~m}$ higher than the base of the lower river system. Hiller et al. (1991) describe this upper river system quite extensively; the present study focuses on its sedimentary characteristics.

The deposits of the upper river system consist of two stratification types: massive silt without any recognizable bedding and epsilon cross bedded sand with fine gravel, situated in channels (Fig. 5). The silt facies represents the vertical accretionary product and the epsilon cross bedded sand and gravel the lateral accretionary deposits (point bar deposits). The point bar deposits not only contain sand and gravel (Fig 6), but also a large amount of wood, including entire (oak) trees (Hiller et al. 1991). The presence of the epsilon cross stratification, the many channel scars, and the large amount of vertical accretion deposits clearly point to a meandering river system. 

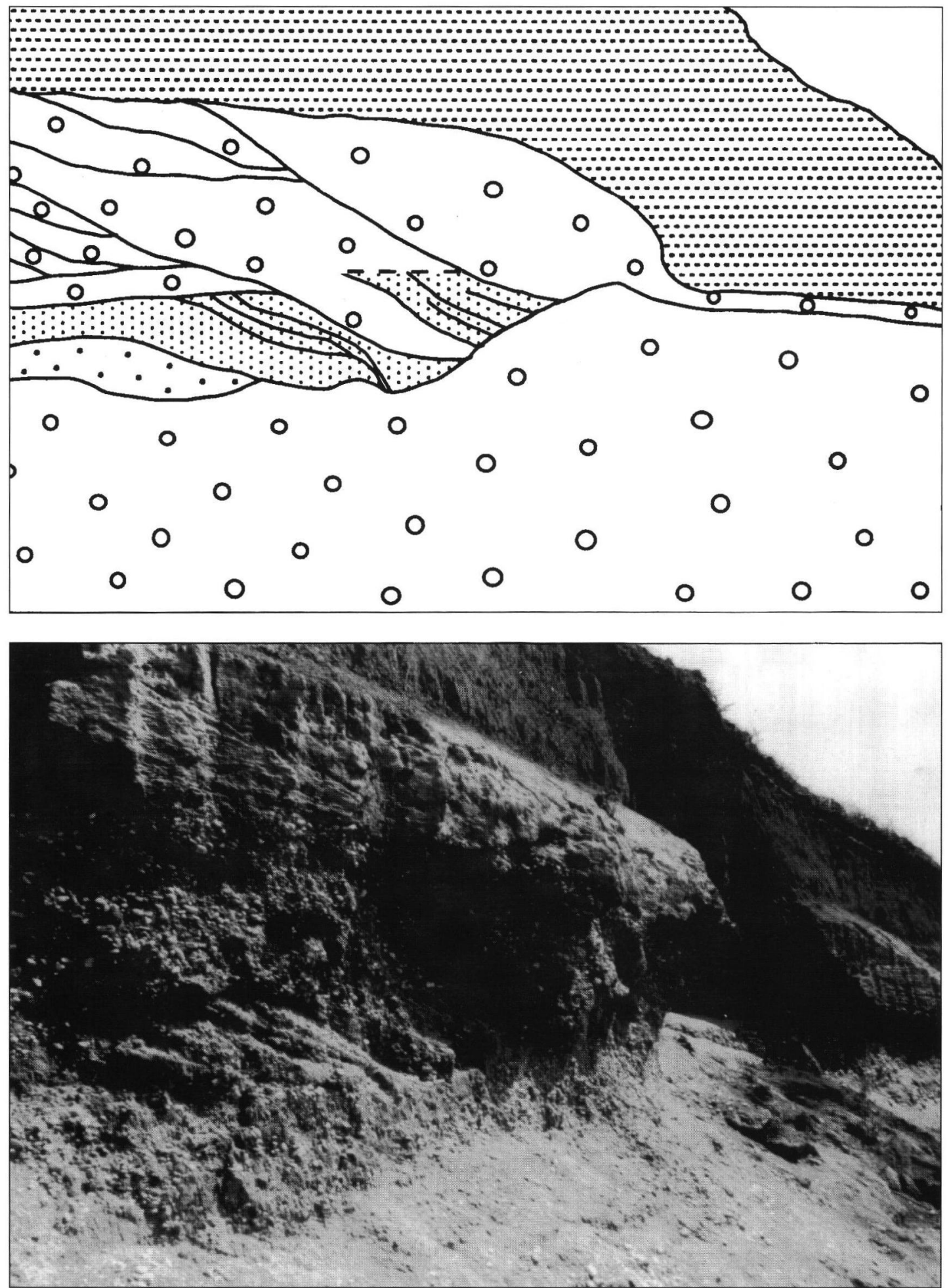

Fig. 6: Epsilon cross bedded sand and gravel of the upper river system in Merseburg-Ost. The cross bedding is directed towards the channel, which is filled with silt (height of cross bedding $0.5 \mathrm{~m}$ ).

Abb. 6: 'Epsilon cross-bedded' Sand und Kies des oberen Fluß-Systems in Merseburg-Ost. Die Schrägschichtung fällt in Richtung der Rinne ein, die mit Schluff gefüllt ist. 


\section{Stratigraphical context and chronology of the river systems}

The lower river system

The lower (braided) river system was active during the Weichselian Late Pleniglacial period (Hiller et al. 1991). Although Wolf \& SEIFERT (1991) stated that the low terrace is pre-Brørup (because of the presence of Brørup-peat on top of it), this seemed unlikely considering the Middle-Late Pleniglacial ages of Steinmüller (1967) and Hiller et al. (1991). Since Wolf \& SEIFERT (1991) were not able to date the base of the fluvial deposits, their low terrace probably was an erosional remnant of older fluvial deposits. Hiller et al. (1991) dated peat within the lower river system 26 - $30 \mathrm{ka}$. Nevertheless, these Middle Pleniglacial ages were established from reworked peat and therefore they suggest only a maximum age. The lower river system probably was active from the boundary Middle/Late Pleniglacial, possibly already during the final part of the Middle Pleniglacial, after a major erosion. This in agreement with LIEDTKE (1993), who reported an erosion phase and a change to braided rivers at the onset of the Late Pleniglacial in northern Germany. The lower level of ice wedge casts in the basal part of the deposits of the lower river system dated from the same period.

The two-fold division of the lower river system, which was caused by a decrease in river discharge, reflects a major boundary. Nevertheless, this break could not be dated properly, because of the lack of datable material. This decrease in river discharge probably took place in the last part of the Late Pleniglacial. During this period the climate was very dry in Poland as well as in the Netherlands and as a result, river discharge decreased.

\section{The middle river system}

The middle river system was active during the Weichselian Late Glacial period, established by means of radiocarbon and palynological data. The start of the activity of the middle river system probably took place at the beginning of the Late Glacial (13 $\mathrm{ka}$ ), in correspondence with findings in other areas (Kozarski 1983, Vandenberghe et al. 1987, Kasse et al. 1994, LIEDTKE 1993).

A palynological section of a peaty channel fill in Cospuden (Fig. 5) shows the Late Dryas-Holocene transition (Fig. 7), indicated by the boundary between regional pollen assemblage zones III and IV (after Firbas 1949). This is confirmed by a ${ }^{14} \mathrm{C}$ date of $10,260 \pm 110 \mathrm{BP}$ (GrN 17156) below the core. The pollen diagram corresponds with the diagrams of the Gatersleben Lake (MülLer 1953) and the Geisel valley (Mania et al. 1993). But, local influences dominate the NAP in the Cospuden diagram. For instance, Artemisia is very low and shows no change in the entire section. This is in contrast to the findings of Müller (1953), who showed that the Late Dryas is characterized by relatively high percentages Artemisia, compared to the Allerød and Preboreal. Nevertheless, his core was taken in lake sediments,

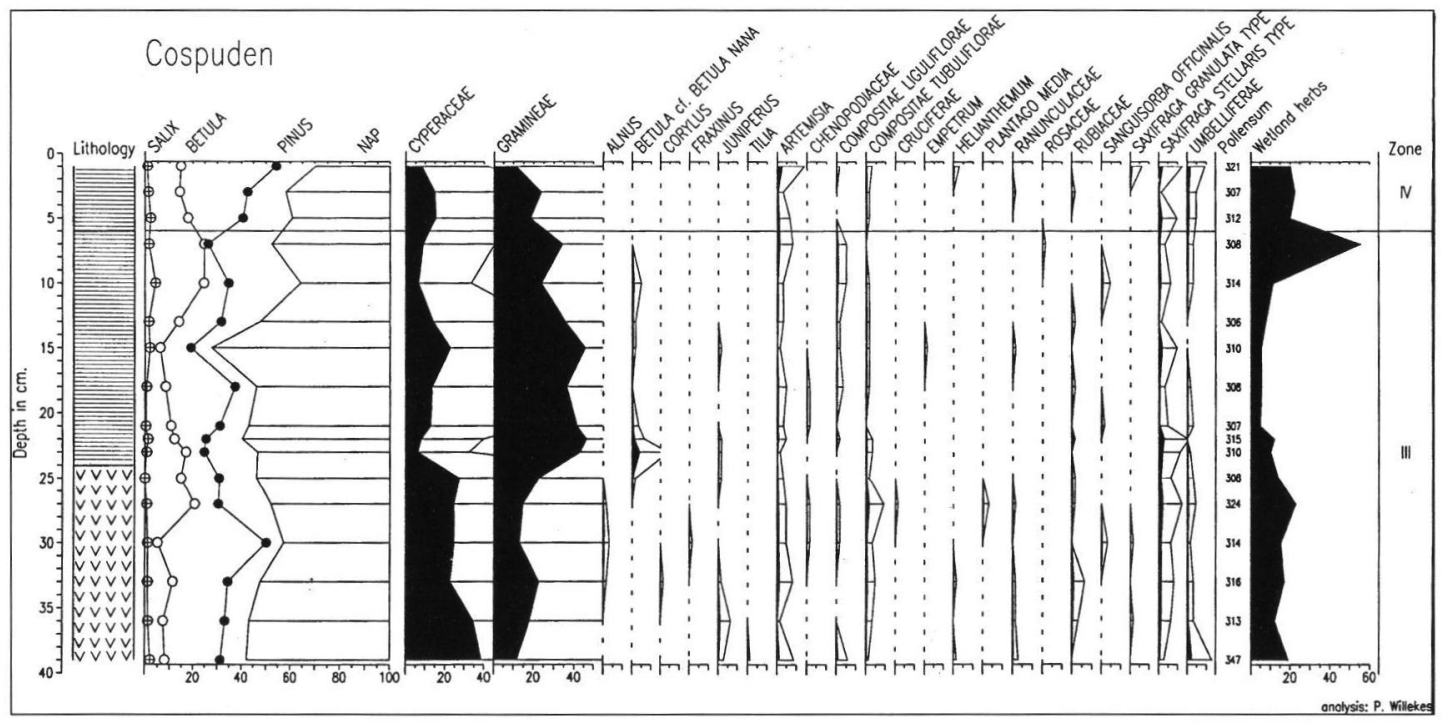

Fig. 7: Palynological profile of the infill of a channel of the middle river system in Cospuden. Location indicated in figure 5 .

Abb. 7: Palynologisches Profil der Füllung von einer Rinne des mittleren Flußsystems in Cospuden. Lage angegeben in Abbildung 5. 
whereas the Cospuden section came from two gully fills. In the latter section the Artemisia was probably continuously present on the borders of the gullies. The established age of the deposits of the upper river system suggests that this river system was still active during the last part of the Late Dryas. The palynological data point to a very limited river activity at the end of the Late Dryas-beginning Holocene: only minor erosion and deposition of clay. Moreover, the overbank deposits in Merseburg-Ost (Fig. 4, sections B and C) were dated by Hiller et al. (1991) 10,950 \pm $190 \mathrm{BP}$ and 10,350 $\pm 190 \mathrm{BP}$, pollen zone III (LitT 1992). Their results showed that also in MerseburgOst the middle river system was active until the end of the Late Dryas.

The upper river system

The upper river system was active during the Holocene and was described extensively by Hituer et al. (1991) in Merseburg-Ost. They dated the soil underlying this meandering river system $6960 \pm 130 \mathrm{BP}$ and dated also various pieces of wood included in point bar deposits of the upper river system. The wood pieces had various ages, of which $8790 \pm 140$ BP (oak tree) was the oldest. This pointed to a start after circa 8790 BP.

However, new data point to an earlier start of activity of the upper river system. The Cospuden pollen diagram and Hiller et al. (1991) suggest a diminished river activity of the middle river system at the onset of the Holocene. New radiocarbon dates on reworked wood within sediments of the upper river system seem to confirm this, although these dates represent only maximum ages. Wood within crevasse splay deposits in open cast mine Goitsche dated $10,135 \pm 25$ BP (GrN-17145) (Fig. 8). Furthermore, wood fragments within trough cross bedded sands (channel deposits) in Merseburg-Ost dated $9315 \pm$ $80 \mathrm{BP}$ (GrN-17146). The upper river system started probably to develop at the beginning of the Preboreal, at 10,000 BP, directly after inactivity of the middle river system. This was already suggested by Hiller et al. (1991), and was in accordance with various studies in north-western Europe (PONS 1957, KOZARSKI 1983, LIEDTKE 1993).

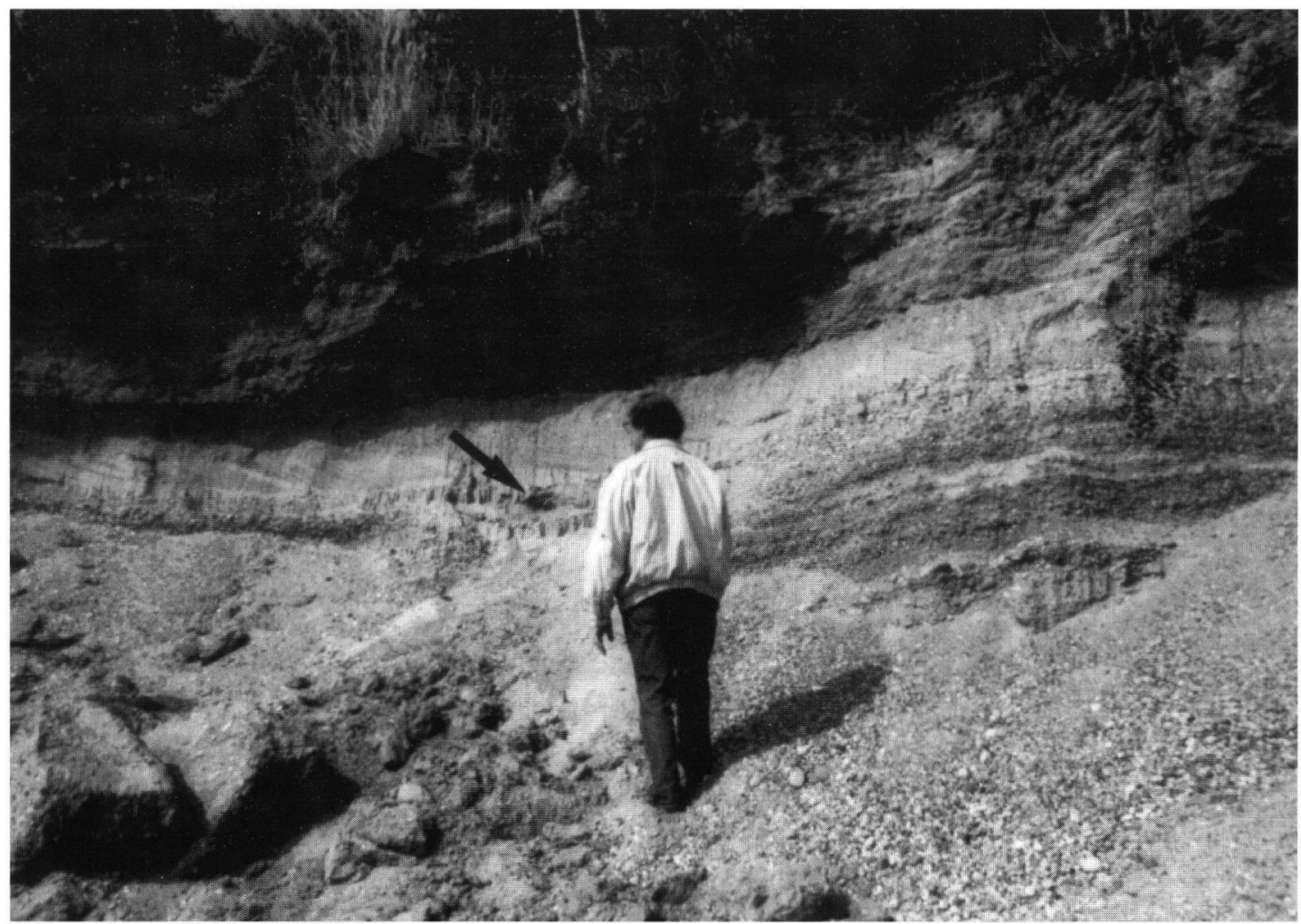

Fig. 8: Deposits of the upper river system on top of gravel of the lower river system in Goitsche. An arrow indicates the location of ${ }^{14} \mathrm{C}$ sample $\mathrm{GrN}-17145(10,135 \pm 25 \mathrm{BP})$, within crevasse splay deposits. They represent the base of the upper river system. Its top is characterized by vertically accreted silt.

Abb. 8: Sedimente des oberen Flußsystems in Goitsche (im Liegenden Kiese des unteren Flußsystems). Ein Pfeil zeigt die Lage der ${ }^{14} \mathrm{C}$ Probe GrN-17145 in Durchbruchsedimenten. Diese Sedimente sind der untere Teil des oberen Flußsystems. Der obere Teil wird von vertikal abgelagertem Schluff repräsentiert. 


\section{River development in relation to climate change (discussion)}

Although temporal variations in a river system are often attributed to external changes such as climate, this needs not always be the case. Schumm (1977) stresses the complex response of a river to an external change. It results in the modification of the river until a new equilibrium has adjusted, and - when thresholds are exceeded - new erosional or depositional events may occur without a new change of external conditions. Therefore, only regional changes in river pattern are climate-induced, since only climate changes and related effects can cause changes in rivers that can be traced from Poland to the Netherlands. Consequently, when erosion phases or changes in sedimentology in this study area also occur in other areas at the same time, they are attributed to climate.

Most of the river changes in the Halle-Leipziger Tieflandsbucht correlate with the fluvial development in other areas. The erosion and development of the lower (braided) river system at the Middle/Late Pleniglacial boundary correspond with the development in the Netherlands. Also in Poland changes in fluvial environment occur on this boundary. The change to a lower discharge regime in the lower river system correlates with the increase in aeolian activity in the Netherlands (VANDEnBerghe \& VAN HuisSTEDEN 1988) and Poland during the last part of the Late Pleniglacial, since both features point to a drier climate. The Late Glacial and Holocene incisions are recognized from Poland (KOZARSki 1983) to the Netherlands (VAndenberghe et al. 1994) and they can therefore be attributed to changes in climate as well.

When these regional river changes are compared, it is striking that all river pattern changes are situated at the beginning of a major climate change and start with an erosion, as the result of adjustment to the new condition. According to VANDENBERGHE (1993), this is due to a delay of reaction of vegetation cover to climate change. At the onset of a cold period erosion is induced by a delay in $\mathrm{de} \mathrm{cr}$ e a s e of vegetation cover, while at the onset of a warm and moister period erosion is induced by a delay in in c rea se of vegetation cover.

The rivers that develop during cold conditions (with permafrost) are braided rivers, while during warm periods meandering rivers develop. During permafrost conditions the frozen subsoil causes a high rate of overland flow, that results in a large sediment supply, because of a sparse vegetation cover. The frozen subsoil also decreases storage capacity, which results in high peak floods. Both the high sediment discharge and the high peak floods cause the development of a braided river system. During warm periods, the increased storage capacity and reduced sediment load, as a result of the dense vegetation cover, result in meandering rivers.

Obviously, in this scenario changes in climate have to be significant, to exceed thresholds and to cause erosion and subsequent development of new river patterns. During the last part of the Late Pleniglacial, the lower river system reacted only slightly on the change to drier conditions, and the change is only reflected in the sedimentary record as a change in sedimentology. A decrease in precipitation caused a decrease in vegetation cover, which resulted in an increased sediment yield. Together with less discharge, this caused the development of wider and shallower channels without erosion.

\section{Conclusions}

Changes in climate have to be significant, to result in changes in river pattern. A river system will exceed its threshold conditions during major changes in climate, which results in erosion and subsequent development of a new river system. However, changes in climate that do not result in exceeding thresholds of a river system can still be reflected in a change in sedimentology within the river system.

At three distinct moments thresholds were passed in the Halle-Leipziger Tieflandsbucht during the Weichselian and onset of Holocene. As a result, three different river systems developed: the lower, middle and upper river systems. The lower river system was a braided river system, which started with an erosion phase at the Weichselian Middle/Late Pleniglacial boundary, when threshold conditions were passed. Its deposits were subdivided in two sedimentologically different parts, of which the upper part reflected a decrease in discharge. This decrease in discharge was due to a drier climate during the last part of the Late Pleniglacial. In this case the threshold for erosion was not passed. At the onset of the Weichselian Late Glacial thresholds were passed again. This resulted in erosion and subsequent development of the middle river system, a meandering river system that was active until the end of the Younger Dryas. This type of river system was also active in the Netherlands and Poland during the same time. Finally, at the beginning of Holocene, threshold conditions were passed again. As a result, the upper river system developed, a meandering river system that was active during the Holocene. During the same period, meandering river systems were also active in the Netherlands and Poland,

\section{Acknowledgments}

I thank Prof. Dr. L. Eissmann and Dr. Th. Litt for introducing me in the brown coal exposures around 
Leipzig and showing me the most interesting sites. Furthermore, I thank MIBRAG for giving permission to work in their exposures and being very cooperative. Thanks also go to Prof. Dr. J. Vandenberghe, who gave constructive comments on previous versions of the manuscript, Mr. H. Sion, who prepared the drawings, and Mr. P. Willekes, who counted the pollen.

\section{References}

BARTKOWSKI, T. (1957): Rozwój polodowcowej sieci hydrograficznej w Wielkopolsce Środkowej (summary: Die Entwicklung des postglazialen Entwässerungssystems im Mittleren Großpolen). - Zesz. Nauk. UAM, Geografika, 1; Poznań:

Bohncke, S., VANdenberghe, J., CoOpe, R., ReIling, R. (1987): Geomorphology and palaeoecology of the Mark river valley (southern Netherlands): palaeoecology, palaeohydrology and climate during the Weichselian Late Glacial. - Boreas, 16: 69-85; Hannover.

BRIDGE, J. S. (1985): Paleochannel pattern inferred from alluvial deposits: a critical evaluation. - J. Sed. Petr., 554: 579-589; Tulsa (Okl.).

BRosCHE, K.-U., (1984): Zur jungpleistozänen Entwicklung des Werratals zwischen Hannoversch-Münden und Philippsthal (öst. Bad Hersfeld). - Eiszeitalter u. Gegenwart, 34: 105-129; Hannover.

EISsmann, L., (1975): Das Quartär der Leipziger Tieflandsbucht und angrenzender Gebiete um Saale und Elbe. Modell einer Landschaftsentwicklung am Rand der europäischen Kontinentalvereisung. - Schriftenreihe für Geologische Wissenschaften, 2; Berlin.

FIRBAS, F. (1949): Spät- und nacheiszeitliche Waldgeschichte Mitteleuropas nördlich der Alpen. - Allgemeine Waldgeschichte, 1; Jena.

Hiller, A., LitT, T., Eissmann, L. (1991): Zur Entwickung der Jungquartären Tieflandstäler im Saale-Elbe-Raum unter besonderer Berücksichtigung von ${ }^{14} \mathrm{C}$-Daten. - Eiszeitalter und Gegenwart, 41: 26-46; Hannover.

Kasse, C., Vandenberghe, J., Bohncke, S. (1994): Climatic change and fluvial dynamics of the Maas during the late Weichselian and early Holocene. - Paläoklimaforschung, 14: (in press); Stuttgart.

KozARSKI, S. (1983): River channel changes in the middle reach of the Warta river valley, Great Poland Lowland. - Quaternary Studies in Poland, 4: 154-169; Wroclaw.

KrZYSZKOWsKI, D. (1990): Middle and Late Weichselian stratigraphy and palaeoenvironments in central Poland. - Boreas, 19: 333-350; Oslo.

LiEDTKE, H. (1993): Phasen periglaziär-geomorphologischer Prägung während der Weichseleiszeit im norddeutschen Tiefland. - Z. Geomorph. 93: 69-94; Berlin.

LITT, T. (1992): Fresh investigations into the natural and anthropogenically influenced vegetation of the earlier Holocene in the Elbe-Saale region, Central Germany. Vegetational History and Archeobotany, 1: 69-74; Berlin.

Mania, D., Seifert, M., Thomae, M. (1993): Spät- und Postglazial im Geiseltal (mittleres Elbe-Saalegebiet). - Eiszeitalter und Gegenwart, 43: 1-22; Hannover.

MülLER, H. (1953): Zur spät- und nacheiszeitlichen Vegetationsgeschichte des mitteldeutschen Trockengebietes. - Nova Acta Leopoldina, N. F. 16-110: 1-67; Leipzig.
Pons, L. J., (1957): De geologie, de bodemvorming en de waterstaatkundige ontwikkeling van het Land van Maas en Waal en een gedeelte van het Rijk van Nijmegen. - Bodemkundige Studies, 3; Wageningen.

REINFELDS, I., NANSON, G. (1993): Formation of braided river floodplains, Waimarakariri river, New Zealand. Sedimentology, 40-6: 1113-1128; Oxford.

RomanovsKIJ, N. N., (1985): Distribution of recently active ice and soil wedges in the USSR. - In: Church, M. and Slaymaker, S. (Hrsg.): Field and Theory. Lectures in Cryogeology, University of British Colombia Press, 154-164; Vancouver.

Ruske, R., WüNSCHE, M. (1964): Zur Gliederung des Pleistozäns im Raum der unteren Unstrut. - Geologie, 13: 211-222; Berlin.

Rust, B. R. (1978): Depositional models for braided alluvium. - In: Miall, A. D. (Hrsg.) Fluvial Sedimentology, Memoirs of the Canadian Society of Petrologists and Geologists, 5: 605-625; Calgary.

Rust, B. R., Koster, E. H. (1984): Coarse alluvial deposits. In: Walker, R. G. (Hrsg.): Facies models, second edition, Geoscience Canada Reprint Series, 1: 53-70; Ontario.

Schumm, S. A. (1977): The fluvial system; New York.

SCHAlich, J., (1968): Die spätpleistozäne und holozäne Talund Bodenentwicklung an der mittleren Rur. - Fortschritte in der Geologie von Rheinland und Westfalen, 16: 339-370; Krefeld.

STEINMÜLlER, A., (1967): Eine weichselzeitliche Schichtenfolge in der Goldenen Aue bei Nordhausen. - Jahrbuch für Geologie, 1: 373-394; Berlin.

VANDENBerghe, J. (1988): Cryoturbations, - In: Clark, M. J. (Hrsg.) Advances in Periglacial Geomorphology; London.

VAndenberghe, J. (1992): Periglacial phenomena and Pleistocene conditions in the Netherlands - an overview. - Permafr. and Perigl. Proc., 3: 363-374; Chichester.

- (1993): Changing fluvial processes under changing periglacial conditions, - Z. Geomorph., 88: 17-28; Berlin.

- J., Bohncke, S., Lammers, W., ZilverberG, L. (1987): Geomorphology and palaeoecology of the Mark valley (southern Netherlands): Geomorphological valley development during the Weichselian and Holocene. Boreas, 16: 55-67; Oslo.

Vandenberghe, J., Kasse, C., Bohncke, S., Kozarski, S. (1994): Climate-related river activity at the Weichselian-Holocene transition: a comparitive study of the Warta and Maas rivers. - Terra nova, 6: (in press); Oxford.

Vandenberghe, J., Van Huissteden, J. (1988): Fluvio-aeolian interaction in a region of continuous permafrost. Proc. $V^{\text {th }}$ int. conf. on permafrost, 876-881; Trondheim.

Van Huissteden, J., Van Der Valk, J., Vandenberghe, J. (1986): Geomorphological evolution of a lowland valley system during the Weichselian. - Earth Surf. Proc. and Landf., 11: 207-216; London.

Wolf, L., Seifert, M. (1991): Die Niederterrassen der Zwickauer Mulde, der Chemnitz und der Zschopau. Z. Geol. Wiss., 19: 347-363; Berlin.

Williams, P. F., Rust, B. R. (1969): Sedimentology of a braided river. - J. Sed. Petr., 39-2: 649-679; Tulsa (Okl.).

Manuskript eingegangen am 25.07.1994 